\title{
A COMPARATIVE STUDY OF LEAD, CADMIUM, ZINC AND SELENIUM CONCENTRATIONS IN PREGNANT AND ABORTED WOMEN
}

\author{
$\mathcal{B Y}$ \\ Sohayla M. Attalla, Sahar A. El-Dakroory, Soad M. Mosad and Hossam E. Goda* \\ Departments of Forensic Medicine \& Clinical Toxicology and Obstetric \& Gynecology*, \\ Faculty of Medicine, Mansoura University, Egypt
}

\begin{abstract}
Lead and cadmium can cause severe acute and chronic health effects including reproductive effects. Pregnant women are among the vulnerable populations. So, the aim of this study was to assess if these metals have a role in cases of repeated abortion. Blood lead, cadmium and serum zinc and selenium concentrations were determined in 40 women complaining of repeated abortion as compared with 24 pregnant women (control). Blood lead and cadmium levels were significantly higher in cases of repeated abortion than those of the control group whereas serum zinc and selenium were significantly lower. The levels of lead and cadmium were also determined in abortuses of the studied cases where they were found to be significantly correlated to their blood levels of lead and cadmium. The difference between lead levels in cases and control were significantly related to risk factors as use of kohl or lead glazed ceramics, coffee or canned food consumption, exposure to smoking, husband's occupation and anaemia. While, cadmium levels were significantly related to risk factors as canned food consumption, husband's occupation, exposure to smoking and anaemia. In conclusion, routine estimation of blood lead and cadmium must be mandatory in cases of repeated abortion. Zinc and selenium supplementation may have a protective effect as they reduce absorption of lead and cadmium.
\end{abstract}

Keywords: Lead, Cadmium, Zinc, Selenium, Repeated Abortion.

\section{INTRODUCTION}

All living and non-living beings are exposed to numerous chemicals persisting in the environment. The scope of the reproductive disorders thus caused in the general population is becoming widely documented, and the possible role of these agents present in the environment on the incidence of these disorders has renewed worldwide attention to review the problem (Kumar, 2008).
Lead, cadmium and mercury are naturally occurring metals, but most human exposure occurs as consequence of human activities. Mounting awareness and concern about environmental pollutants and their adverse health effects have led to an increase in measures to protect the public from avoidable exposures (McKelvey et al., 2007).

Lead and cadmium are highly toxic metals for humans and other mammals, 
both are pervasive in the human environment and accumulate in the human body over life time, including prenatal life (especially lead). Apart from numerous sources of occupational exposure to each of the metals, the most important non occupational sources are food (especially seafood from metal-polluted areas), water (lead, mostly from lead pipes in contact with soft and acidic water), air (especially lead from gasoline in dense traffic areas), lead based paints of housing and smoking habits (cadmium and to lesser extent lead from tobacco) (Telisman et al., 2000).

The World Health Organization has shown that dietary cadmium exposure has a very wide range. So it poses a significant threat to the human population and environment. Cadmium-contaminated topsoil is considered the most likely mechanism for the greatest human exposure through uptake into edible plants and tobacco (Patrick, 2003).

Cadmium occurs naturally in some soils in addition to being deposited through emissions from mining operations and fossil fuel combustion, application of phosphate fertilizer or sewage sludge, and disposal of cadmium containing products (Agency for Toxic Substance and Disease Registry (ATSDR), 1999).

Only a few modern epidemiologic studies have addressed lead (Synder et al.,
2000) and cadmium on reproductive outcome (Telisman et al., 2000), so the present study was designed to estimate these metals in abortuses and in blood of aborted women compared to pregnant women.

\section{PATIENTS AND METHODS}

The present study was conducted on 64 women divided into two groups. The first group included 40 women with at least two miscarriages in the first trimester (first 14 weeks gestation), aged from 20 to 39 years, who attended Obstetrics \& Gynecology Department of Mansoura University Hospital over one year period. They were admitted complaining of inevitable miscarriage and surgical evacuation or manual vacuum aspiration was required. All women were subjected to ultrasound investigation to ensure diagnosis and exclude major anomalies of the uterus. The second group consisted of 24 females with no history of miscarriage and they were pregnant (controls) without problems and their age, weight, and height were matched with cases. None of the aborted women or controls was receiving medication or suffering from any infection during the study. Informed consent was taken from all women to share in this study. A thorough history was taken from each woman with special emphasis on:

1- Age, residence and occupation.

2- Lead exposure risk factors questionnaire included; Usage of kohl and/ 
or lead glazed ceramics; old housing and lead pipes; husband occupation especially workers in painting, solders, drivers; cigarette smoking of the husband (light, moderate or heavy according to Ferris Smoking Index (packs of cigarettes / day x 365 $x$ number of years of smoking).

3- Cadmium exposure risk factors questionnaire included; Increased consumption of canned foods, seafood, coffee and exposure to smoking (passive smokers).

4- History of diabetes, hypertension, hepatic and renal diseases.

5- History of drug or alcohol intake.

For each participant, ten $\mathrm{ml}$. venous blood were withdrawn from anticubital vein under complete aseptic condition, added to EDTA, into polypropylene tubes, shacked gently for analysis of lead and cadmium and $5 \mathrm{ml}$ were separated to obtain serum for zinc and selenium estimation. One gram from abortuses (product of conception) was put in a clean flask. Both blood and abortuses kept at $4^{\circ} \mathrm{C}$ until assay.

Digestion of blood and aborted samples were done by wet method of digestion (nitric-perchloric acid) according to the method of Vanloon (1985). Analysis of lead, cadmium and selenium was done by the method of Stockwell and Corns (1993) by using Perkin - Elmer 2380 Atomic Absorption Spectrophotometer (AAS cold steam technique in combination with flow injection system at Mansoura Faculty of Science). Preparation of standards and samples was carried out under clean conditions using deionized water. Analytic standards of lead, cadmium and zinc were prepared from solutions of metal nitrate (BDH, UK), with concentration of $1000 \mathrm{mg} / \mathrm{L}$. All chemicals and reagents used were of ultra pure reagent grade. All glassware and plastic ware were washed three times with deionized water, and then soaked in $20 \%$ nitric acid overnight. After soaking the glassware was rinsed three times with deionized water and dried. Quality assurance was achieved by measuring blank test solutions. All metal contents were measured in duplicate (S.D. $<10 \%$ ) by the working curve method.

Data were compared by using student's t-test (to compare two groups) and Anova test for multiple groups comparison. Chi square $\left(\mathrm{x}^{2}\right)$ was used for qualitative data (frequency and proportion). Correlation co-efficiency was used to test association between variables. Significance was considered when $\mathrm{P}$ value is less than 0.05 . These data were run on an IBM compatible personal computer by using Statistical Package for Social Scientists (SPSS) for windows 11 (SPSS Inc., Chicago, IL, USA).

\section{RESULTS}

Blood lead and cadmium levels were 
highly significantly higher in cases of repeated abortion $(19.78 \pm 3.85$ and $7.51 \pm$ $1.02 \mathrm{ug} / \mathrm{dl}$ respectively) than those of the pregnant women $(10.53 \pm 1.01$ and $5.06 \pm$ $0.81 \mathrm{ug} / \mathrm{dl}$ respectively) whereas serum zinc and selenium were significantly lower in aborted women $(77.01 \pm 11.55 \mathrm{ug} \%$ and $46.72 \pm 5.54 \mathrm{ng} / \mathrm{ml}$ respectively) than those of the pregnant women $(90.01 \pm$ $10.77 \mathrm{ug} \%$ and $63.93 \pm 3.03 \mathrm{ng} / \mathrm{ml}$ respectively). The levels of lead and cadmium in abortus were $3.99 \pm 0.743$ and $1.89 \pm 0.26$ ug / gm respectively (Table 1 ).

Table (2) Show the characteristics of the studied cases.

Blood lead level was higher with statistical significance in cases with positive kohl usage, anemia, use of lead glazed ceramic, coffee consumption (more than 3 cups/day), canned food consumption, recent paint, husband occupation (merchant, mechanic and painter), husband smoking (heavy smoker) (Table 3).

Blood cadmium level was higher with highly statistical significance in cases with husband occupation (merchant, mechanic and painter) and those exposed to heavy husband smoking. There was also higher blood cadmium level with statistical significance in cases with canned food consumption (Table 4).

Table (5) shows highly significant posi- tive correlations between both blood lead $(r=0.995)$ and cadmium level $(r=0.984)$ and their levels in abortuses (Graphs 1 \& 2 ). There was highly significant negative correlation between blood lead and zinc ( $\mathrm{r}$ $=-0.792$ ) and also between blood lead and selenium ( $\mathrm{r}=-0.840)$ (Graphs $3 \& 4)$. There was a highly significant negative correlation between blood cadmium level and zinc $(r=-0.910)$ and also between blood cadmium level and selenium $(r=-0.836)$ (Graphs 5 \& 6).

\section{DISCUSSION}

Exposure to toxic metals has become an increasingly recognized source of illness worldwide (Patrick, 2003). However, the effect of heavy metals such as mercury, lead, cadmium, chromium etc. on male and female reproduction has been studied in detail in various experimental animal species but data on humans are steadily building up (Kumar, 2008).

Lead is one of the most hazardous and cumulative environmental pollutants that introduced into the environment by humans. It affects embryonic development and functioning of reproductive system (Milnes et al., 2006). Cadmium is considered one of the most toxic substances in the environment due to its wide range of organ toxicity and long elimination half-life of 10 - 30 years (Patrick, 2003). 
The results of the present study showed high blood lead levels in aborted women when compared to pregnant. This was in accordance with the result of LamadridFigueroa et al. (2007) who concluded that spontaneous abortion is related to the plasma / blood lead ratio, which could be due to a greater availability of placental barrier crossing lead for a given blood lead concentration in some women.

The observed high blood lead levels of the studied aborted women in the present study may be attributed to variable environmental sources for exposure with absence of general preventive strategies for controlling these sources. Contaminated soils from airborne pollution, use of leaded pesticides or from paints of the exterior of nearby building, use of leaded water pipe lines and living near heavy automobile traffic using leaded gasoline (urban areas) are all factors contributing to lead exposure among women (Klaassen, 2006).

The result of the present study revealed a statistically significant elevation of lead levels in women using kohl. Kohl is composed of lead sulfide, so it is considered a continuous source of lead exposure with possible absorption from skin. Also, there was high blood lead in aborted women with positive husband smoking. Results of this work are consistent with previous report of positive association between pas- sive and active smoking and blood lead (Mannino et al., 2005).

There was also higher blood lead level with statistical significance in cases of positive anemia, In accordance with this result, WHO, (2000) reported that atypical physiological states may alter the rate of absorption of lead from the intestine into the blood. In particular, iron and calcium can compete for the active transport of lead into the blood. As a result lead uptake is greater when other minerals are not present.

Higher blood lead level was found in aborted women with husband occupation (mechanic, painter and merchant). Paternal exposure to lead may be related to spontaneous abortions by three pathways; 1- Paternal lead is passed through semen to the mother, 2- Lead in the father's work clothes, equipments, hands, etc., is a source of exposure for the mother, 3- Lead burden in the father alters his sperm. The first scenario would not necessarily results in elevated maternal blood lead, while the second would likely have such an effect and could have been operating in our study subjects. The third explanation may have a role, this is consistent with Eibensteiner et al. (2005), Hernandez-Ochoa et al. (2005), Jurasovic et al. (2004) and Telisman et al. (2007) who concluded that Lead may adversely affect sperm shape, motility, and DNA integrity. 
The present study showed significant positive correlation between blood lead in aborted women and its level in in tissues of aborted foetus. This is mainly related to transplacental transfer (Abd El-Hameed, 2008).

Elevated cadmium levels were found in the present work in aborted women when compared with pregnant women. Ronco et al., (2005 a) showed in a previous study that placental levels of cadmium were inversely correlated to offspring birth weight. Foetal growth restriction could be related to impaired placental function (due to toxic metals), thus inhibiting appropriate transfer of essential nutrients to the foetus, which are indispensable for life maintenance and normal development and growing (Osada et al., 2002). In addition, cadmium has been linked to poor human semen quality, abnormal sperm morphology, decrease in sperm motility and DNA damage (Xu et al., 2003).

Blood cadmium levels were most strongly associated with smoking status. A recent study by Nas et al. (2007) reported that smoking has harmful effects on tubal function and menstrual cycle resulting in subsequent increased uterine contractility and failure of quiescence of the uterus.

As regards zinc and selenium levels in the studied cases, there was a significant inverse correlation between their levels and lead and cadmium levels. High levels of cadmium in placenta induce high levels of metallothionein (MT), a protein involved in the intracellular homeostasis of cadmium and zinc (Ronco et al., 2005 b). Thus, additional MT not only retains cadmium in the placenta to protect the foetus, but also may affect foetus-placental zinc dynamics, which in turn may lead to reduced zinc bioavailability to the foetus and thus contribute to weight impairment (Ronco and Lianos, 2009). Zinc is an essential micronutrient for foetal growth and for proper immune system function (Wellinghausen, 2001).

Although lead appears to produce relative zinc deficiency, cadmium appears to mainly affect the distribution of zinc in the body (Telisman et al., 2000). Alteration in the amount and/or biologic availability of zinc in certain body compartments through the lead and cadmium related decrease in the capacity of MT to provide optimum supply of zinc to the cell.

It's known that pregnancy, due to the mitochondria rich placenta, is a condition that favors oxidative stress (Myatt and Cui, 2004). Mechanisms against reactive oxygen species (ROS) increase during pregnancy and protect the foetus (Casanueva and Viteriy, 2003). One of the main defense mechanisms against effects of ROS is constituted by selenium and copper/zinc-dependent enzymes, glutathione 
peroxidase (GPx) and superoxide dismutase (SOP). It has been shown that those enzymes may be inhibited by several heavy metals. Therefore, the presence of heavy metals in placenta may be detrimental for placental GPx and SOD activities and as a result the foetus is subjected to some degree of oxidative stress which may result in potential damage (Masso et al., 2007). So, we hypothesize that an imbalance of essential metals like zinc and selenium in this study could contribute to excessive ROS production affecting foetal growth and development.

In conclusion, estimation of lead and cadmium may be important in cases of unexplained spontaneous abortion. Each woman with unexplained spontaneous abortion should be subjected to heavy metals estimation. Reduction of an increased heavy metal body load is mandatory. Chelating therapy should be done cautiously in a hospital to choose the proper agent, suitable route and to avoid the possible side effects.

Females should be advised to optimize caloric, iron and calcium intake specifically to reduce lead absorption. Supplementation of zinc and selenium during pregnancy may reduce absorption of heavy metals reducing its deleterious effect.

Ongoing surveillance of exposure to toxic substances is essential for identifying and targeting high-risk groups, evaluating interventions, tracking exposure overtime and monitoring exposure during emergency situations. Because lead and cadmium are known to harm the foetus and cross the placenta, it is critical to support efforts to track and develop methods of intervention to reduce exposures in women of reproductive age.

Table (1): Lead and cadmium levels among the studied cases.

\begin{tabular}{|l|c|c|cc|}
\hline \multicolumn{1}{|c|}{ Parameters } & $\begin{array}{c}\text { Cases of abortion } \\
(\mathbf{n}=\mathbf{4 0}) \\
\text { Mean } \pm \text { S.D }\end{array}$ & $\begin{array}{c}\text { Controls } \\
(\mathbf{n}=\mathbf{2 4}) \\
\text { Mean } \pm \text { S.D }\end{array}$ & \multicolumn{2}{|c|}{ Statistical data } \\
\hline 1) Blood lead $(\boldsymbol{\mu g} / \mathbf{d L}):$ & $19.78 \pm 3.85$ & $10.53 \pm 1.01$ & $\mathrm{t}=-8.59$ & $\mathrm{P}<0.0001$ \\
2) Blood cadmium $(\boldsymbol{\mu g} / \mathbf{d L}):$ & $7.51 \pm 1.02$ & $5.06 \pm 0.81$ & $\mathrm{t}=-6.26$ & $\mathrm{P}<0.0001$ \\
3) Blood zinc $(\boldsymbol{\mu g} \mathbf{\%}):$ & $77.01 \pm 11.55$ & $90.01 \pm 10.77$ & $\mathrm{t}=2.71$ & $\mathrm{P} 0.020$ \\
4) Blood selenium $(\mathbf{n g} / \mathbf{m L}):$ & $46.72 \pm 5.54$ & $63.93 \pm 3.03$ & $\mathrm{t}=9.55$ & $\mathrm{P}<0.0001$ \\
5) Abortus lead $(\boldsymbol{\mu g} / \mathbf{g m}):$ & $3.99 \pm 0.743$ & & & \\
6) Abortus cadmium $(\boldsymbol{\mu g} / \mathbf{g m}):$ & $1.89 \pm 0.26$ & & & \\
\hline
\end{tabular}

Significant at $\mathrm{p} \leq 0.05$, Highly significant at $\mathrm{p} \leq 0.001$. 
Table (2): Characteristics of the studied cases.

\begin{tabular}{|c|c|c|c|c|c|}
\hline \multirow{2}{*}{\multicolumn{2}{|c|}{ Parameters }} & \multirow{2}{*}{$\begin{array}{c}\text { Cases of abortion } \\
n=40\end{array}$} & \multirow{2}{*}{$\begin{array}{c}\text { Controls } \\
\mathrm{n}=\mathbf{2 4}\end{array}$} & \multicolumn{2}{|c|}{ Statistical data } \\
\hline & & & & Test & $\mathbf{P}$ \\
\hline Age (years): & Mean \pm S.D & $28.70 \pm 3.28$ & $28.75 \pm 2.93$ & $\mathrm{t}=0.000$ & 1 \\
\hline Residence: & $\begin{array}{l}\text { Urban } \quad \mathrm{n}(\%) \\
\text { Rural }\end{array}$ & $\begin{array}{l}26(65) \\
14(35)\end{array}$ & $\begin{array}{l}14(58.3) \\
10(41.7)\end{array}$ & $\mathrm{X}^{2}=2$ & 0.157 \\
\hline Occupation & $\begin{array}{l}\text { f the studied cases: } \\
\text { Employee } \mathrm{n}(\%) \\
\text { Farmer } \\
\text { Housewife } \\
\text { Teacher }\end{array}$ & $\begin{array}{c}20(50) \\
2(5) \\
14(35) \\
4(10)\end{array}$ & $\begin{array}{c}6(25) \\
4(16.7) \\
8(33.3) \\
6(25)\end{array}$ & $\mathrm{X}^{2}=8.5$ & 0.037 \\
\hline Kohl usage: & $\begin{array}{l}\text { Positive } \quad n(\%) \\
\text { Negative }\end{array}$ & $\begin{array}{l}26(65) \\
14(35)\end{array}$ & $\begin{array}{l}12(50) \\
12(50)\end{array}$ & $\mathrm{X}^{2}=1.125$ & 0.289 \\
\hline Anaemia: & $\begin{array}{l}\text { Positive } \quad n(\%) \\
\text { Negative }\end{array}$ & $\begin{array}{l}22(55) \\
18(45)\end{array}$ & $\begin{array}{c}8(33.3) \\
16(66.7)\end{array}$ & $X^{2}=0.125$ & 0.724 \\
\hline Use of lead \& & $\begin{array}{l}\text { lazed ceramic: } \\
\text { Positive } \quad \mathrm{n}(\%) \\
\text { Negative }\end{array}$ & $\begin{array}{l}20(50) \\
20(50)\end{array}$ & $\begin{array}{c}8(33.3) \\
16(66.7)\end{array}$ & $\mathrm{X}^{2}=0.5$ & 0.480 \\
\hline Coffee const & $\begin{array}{l}\text { mption: } \\
\text { Positive } \quad \mathrm{n}(\%) \\
\text { Negative }\end{array}$ & $\begin{array}{l}20(50) \\
20(50)\end{array}$ & $\begin{array}{l}10(41.7) \\
14(58.3) \\
\end{array}$ & $\mathrm{X}^{2}=0.125$ & 0.724 \\
\hline Canned fooc & $\begin{array}{l}\text { consumption: } \\
\text { Positive n }(\%) \\
\text { Negative }\end{array}$ & $\begin{array}{l}18(45) \\
22(55)\end{array}$ & $\begin{array}{c}8(33.3) \\
16(66.7)\end{array}$ & $\mathrm{X}^{2}=1.125$ & 0.289 \\
\hline Old houses & $\begin{array}{l}\text { lead pipes: } \\
\text { Positive } \quad n(\%) \\
\text { Negative }\end{array}$ & $40(100)$ & $24(100)$ & & \\
\hline Recent pain & $\begin{array}{l} \\
\text { Positive } \\
\text { Negative }\end{array}$ & $\begin{array}{l}12(30) \\
28(70)\end{array}$ & $\begin{array}{c}4(16.7) \\
20(83.3)\end{array}$ & $X^{2}=8$ & 0.005 \\
\hline Husband oc & $\begin{array}{ll}\text { upation: } & \\
\text { Employee } & \mathrm{n}(\%) \\
\text { Farmer } & \\
\text { Engineer } & \\
\text { Teacher } & \\
\text { Mechanic } & \\
\text { Painter } & \\
\text { Merchant } & \\
\end{array}$ & $\begin{array}{l}12(30) \\
4(10) \\
2(5) \\
4(10) \\
8(20) \\
8(20) \\
2(5) \\
\end{array}$ & $\begin{array}{l}8(33.3) \\
4(16.7) \\
4(16.7) \\
4(16.7) \\
2(8.3) \\
2(8.3) \\
-----\end{array}$ & $\mathrm{X}^{2}=11.31$ & 0.079 \\
\hline Husband sm & $\begin{array}{l}\text { oking: } \\
\text { Non-smoker n (\%) } \\
\text { Mild smoker } \\
\text { Moderate smoker } \\
\text { Heavy smoker }\end{array}$ & $\begin{array}{l}10(25) \\
8(20) \\
4(10) \\
18(45)\end{array}$ & $\begin{array}{c}14(58.3) \\
4(16.7) \\
4(16.7) \\
2(8.3) \\
\end{array}$ & $X^{2}=5$ & 0.172 \\
\hline
\end{tabular}

Significant at $\mathrm{p} \leq 0.05$, Highly significant at $\mathrm{p} \leq 0.001$.

$\mathrm{X}^{2}$ : Chi square test. 
Table (3): Statistical comparison of blood lead concentrations in the different categories of the studied risk factors.

\begin{tabular}{|c|c|c|c|c|}
\hline \multirow{2}{*}{\multicolumn{2}{|c|}{ Parameters }} & \multirow{2}{*}{$\begin{array}{c}\text { Blood lead level } \\
\text { (Mean } \pm \text { SD) }\end{array}$} & \multicolumn{2}{|c|}{ Statistical analysis } \\
\hline & & & Test & $\mathbf{P}$ \\
\hline Residence: & $\begin{array}{l}\text { Urban } \\
\text { Rural }\end{array}$ & $\begin{array}{l}20.02 \pm 3.68 \\
19.33 \pm 4.40\end{array}$ & $\begin{array}{c}\text { One way Anova } \\
\mathrm{F}=0.142\end{array}$ & 0.711 \\
\hline Occupation o & $\begin{array}{l}\text { of the studied cases:: } \\
\text { Employee } \\
\text { Farmer } \\
\text { Housewife } \\
\text { Teacher }\end{array}$ & $\begin{array}{c}19.52 \pm 4.08 \\
18.6 \\
19.77 \pm 4.14 \\
21.7 \pm 4.38\end{array}$ & $\begin{array}{c}\text { One way Anova } \\
\mathrm{F}=0.185\end{array}$ & 0.906 \\
\hline Kohl usage: & $\begin{array}{l}\text { Positive } \\
\text { Negative }\end{array}$ & $\begin{array}{l}22.33 \pm 3.29 \\
16.04 \pm 1.25\end{array}$ & 5.9 & 0.001 \\
\hline Anaemia: & $\begin{array}{l}\text { Positive } \\
\text { Negative }\end{array}$ & $\begin{array}{l}22.25 \pm 3.38 \\
16.83 \pm 1.79\end{array}$ & 6.20 & 0.000 \\
\hline Use of lead gl & $\begin{array}{l}\text { lazed ceramic: } \\
\text { Positive } \\
\text { Negative }\end{array}$ & $\begin{array}{l}22.36 \pm 2.79 \\
17.20 \pm 2.95\end{array}$ & 3.63 & 0.006 \\
\hline Coffee consu & $\begin{array}{l}\text { mption: } \\
\text { Positive } \\
\text { Negative }\end{array}$ & $\begin{array}{c}22.51 \pm 2.89 \\
17.05 \pm 2.52 \\
\end{array}$ & 5.94 & 0.000 \\
\hline Canned food & $\begin{array}{l}\text { consumption: } \\
\text { Positive } \\
\text { Negative }\end{array}$ & $\begin{array}{l}22.86 \pm 3.16 \\
17.39 \pm 2.20\end{array}$ & 4.07 & 0.004 \\
\hline Old houses \& & $\begin{array}{l}\text { lead pipes: } \\
\text { Positive } \\
\text { Negative }\end{array}$ & $\begin{array}{c}19.78 \pm 3.85 \\
-----\end{array}$ & & \\
\hline Recent paint: & $\begin{array}{l}\text { Positive } \\
\text { Negative }\end{array}$ & $\begin{array}{l}24.38 \pm 1.87 \\
18.83 \pm 2.92 \\
\end{array}$ & 5.08 & 0.004 \\
\hline Husband occ & $\begin{array}{l}\text { upation: } \\
\text { Employee } \\
\text { Farmer } \\
\text { Engineer } \\
\text { Teacher } \\
\text { Mechanic } \\
\text { Painter } \\
\text { Merchant }\end{array}$ & $\begin{array}{c}16.88 \pm 1.64 \\
17.25 \pm 1.91 \\
15.3 \\
16.65 \pm 1.06 \\
24.57 \pm 0.80 \\
21.82 \pm 2.28 \\
25.6 \\
\end{array}$ & $\begin{array}{c}\text { One way Anova } \\
\mathrm{F}=14.85\end{array}$ & 0.000 \\
\hline Husband sme & $\begin{array}{l}\text { oking: } \\
\text { Non-smoker } \\
\text { Mild smoker } \\
\text { Moderate smoker } \\
\text { Heavy smoker } \\
\end{array}$ & $\begin{array}{c}16.74 \pm 1.30 \\
16.15 \pm 1.69 \\
19.3 \pm 2.69 \\
23.19 \pm 2.61 \\
\end{array}$ & $\begin{array}{c}\text { One way Anova } \\
\mathrm{F}=14.08\end{array}$ & 0.000 \\
\hline
\end{tabular}

Significant at $\mathrm{p} \leq 0.05$, Highly significant at $\mathrm{p} \leq 0.001$.

F : One way Anova. 
Table (4) : Statistical comparison of blood cadmium concentrations in the different categories of the studied risk factors.

\begin{tabular}{|c|c|c|c|c|}
\hline \multirow{2}{*}{\multicolumn{2}{|c|}{ Parameters }} & \multirow{2}{*}{$\begin{array}{c}\text { Blood cadmium level } \\
(\text { Mean } \pm \text { SD })\end{array}$} & \multicolumn{2}{|c|}{ Statistical analysis } \\
\hline & & & Test & $\mathbf{P}$ \\
\hline Residence: & $\begin{array}{l}\text { Urban } \\
\text { Nural }\end{array}$ & $\begin{array}{l}7.59 \pm 0.78 \\
7.34 \pm 1.43\end{array}$ & 0.887 & 0.409 \\
\hline Occupation: & $\begin{array}{l}\text { Employee } \\
\text { Farmer } \\
\text { Housewife } \\
\text { Teacher } \\
\end{array}$ & $\begin{array}{c}7.53 \pm 1.01 \\
6.15 \\
7.57 \pm 1.18 \\
7.8 \pm 0.27 \\
\end{array}$ & $\begin{array}{c}\text { One way Anova } \\
\mathrm{F}=0.616\end{array}$ & 0.614 \\
\hline Anaemia: & $\begin{array}{l}\text { Positive } \\
\text { Negative }\end{array}$ & $\begin{array}{l}7.94 \pm 1.05 \\
6.98 \pm 0.73\end{array}$ & 3.125 & 0.014 \\
\hline Coffee consun & $\begin{array}{l}\text { mption: } \\
\text { Positive } \\
\text { Negative }\end{array}$ & $\begin{array}{l}8.17 \pm 0.88 \\
6.85 \pm 0.68\end{array}$ & -1.209 & 0.257 \\
\hline Canned food & $\begin{array}{l}\text { consumption: } \\
\text { Positive } \\
\text { Negative }\end{array}$ & $\begin{array}{l}8.33 \pm 0.57 \\
6.83 \pm 0.77\end{array}$ & 3.747 & 0.006 \\
\hline Husband Oce & $\begin{array}{l}\text { upation: } \\
\text { Employee } \\
\text { Farmer } \\
\text { Engineer } \\
\text { Teacher } \\
\text { Mechanic } \\
\text { Painter } \\
\text { Merchant }\end{array}$ & $\begin{array}{c}6.85 \pm 0.55 \\
6.07 \pm 0.11 \\
6.4 \\
7.2 \pm 0.68 \\
8.19 \pm 0.25 \\
8.59 \pm 0.53 \\
8.92 \\
\end{array}$ & $\begin{array}{c}\text { One way Anova } \\
\qquad \mathrm{F}=11.91\end{array}$ & 0.000 \\
\hline Husband Smo & $\begin{array}{l}\text { oking: } \\
\text { Non smoker } \\
\text { Mild smoker } \\
\text { Moderate smoker } \\
\text { Heavy smoker }\end{array}$ & $\begin{array}{l}6.54 \pm 0.26 \\
6.55 \pm 0.72 \\
7.84 \pm 0.23 \\
8.39 \pm 0.55\end{array}$ & $\begin{array}{c}\text { One way Anova } \\
\mathrm{F}=18.97\end{array}$ & 0.000 \\
\hline
\end{tabular}

Significant at $\mathrm{p} \leq 0.05$, Highly significant at $\mathrm{p} \leq 0.001$.

Table (5): Correlation test between the studied cases.

\begin{tabular}{|l|l|c|}
\hline \multicolumn{2}{|c|}{ Items of comparison } & Correlation test \\
\hline Blood lead level & Abortus lead level & $\mathrm{r}=0.995, \mathrm{p}=0.000$ \\
\hline Blood cadmium level & Abortus cadmium level & $\mathrm{r}=0.984, \mathrm{p}=0.000$ \\
\hline Blood lead level & Blood zinc level & $\mathrm{r}=-0.792, \mathrm{p}=0.000$ \\
\hline Blood lead level & Blood selenium level & $\mathrm{r}=-0.840, \mathrm{p}=0.000$ \\
\hline Blood cadmium level & Blood zinc level & $\mathrm{r}=-0.910, \mathrm{p}=0.000$ \\
\hline Blood cadmium level & Blood selenium level & $\mathrm{r}=,-0.836, \mathrm{p}=0.000$ \\
\hline
\end{tabular}

Significant at $\mathrm{r} \geq 0.75$ and $\mathrm{p} \leq 0.05$

$\mathrm{r}$ : correlation test. 


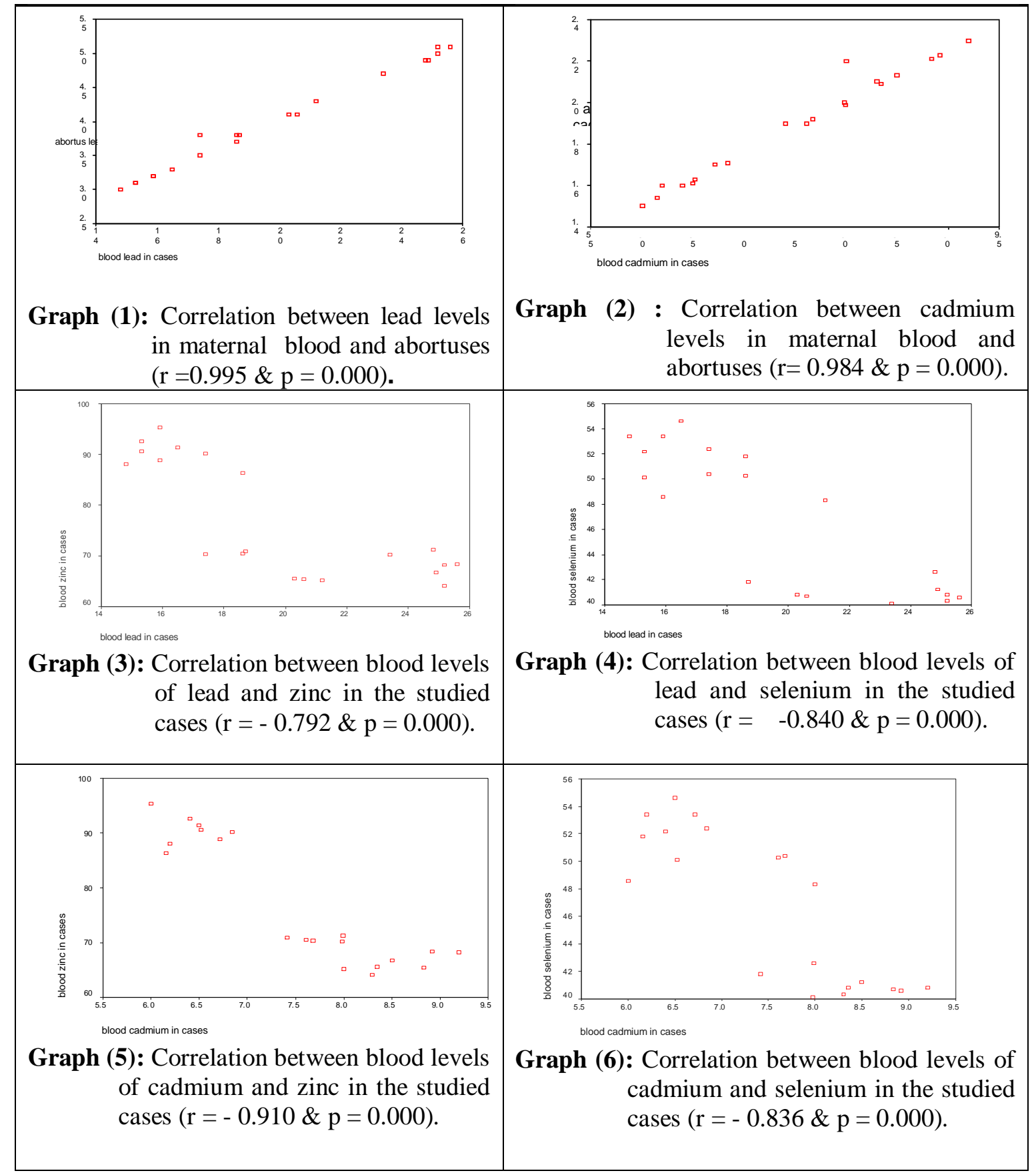




\section{REFERENCES}

Abd El-Hameed, A.; Shalaby, S. and Mohamed, A. (2008) : "Maternal blood and milk lead concentrations following exposure during pregnancy with emphasis to its residues in tissues of aborted foeti of goats". Asian J. Anim.Vet.Adv.,3(1):42-46.

Agency For Toxic Substances and Disease Registry (ATSDR) (1999) : Toxicological profile for cadmium. Atlanta, GA: US Department of Health and Human Services, Public Health Service:242.

Casanueva, E. and Viteriy, F. (2003) : "Iron and oxidative stress in pregnancy". J.Nutr.,133:1700s-1708s.

Eibensteiner, L.; Del Carpio Sanz, A.; Frumkin, H.; Gonzales, C. and Gonzales, G. F. (2005) : "Lead exposure and semen quality among traffic police in Arequipa, Peru". Int. J. Occup. Environ. Health, 11:161-166.

Hernandez-Ochoa, I.; Garcia-Vargas, G.; Lopez-Carrillo, L.; Rubio-Andrade, M.; Moran-Martinez, J.; Cebrian, M. E.; et al. (2005) : "Low lead environmental exposure alters semen quality and sperm chromatin condensation in northern Mexico". Reprod. Toxicol., 20:221-228.

Jurasovic, J.; Cvitkovic, P.; Pizent, A.; Colak, B. and Telisman, S. (2004) :
"Semen quality and reproductive endocrine function with regard to blood cadmium in Croatian male subjects". Biometals, 17:735-743.

Klaassen, C. (2006) : Heavy metals and heavy-metal antagonists. In : The Pharmacological Basis of Therapeutics. Goodman and Gilman_s (Eds.), 11th ed., Chapter 65, McGraw-Hill, New York, Chicago, San Francisco, P.P.1753 - 1800.

Kumar, S. (2008) : "Is environmental exposure associated with reproductive health impairments?". J.Turkish-German Gynecol. Assoc., 9(1): 60-69.

Lamadrid-Figueroa, H.; Tellez-Rojo, M.; Hernandez-Avila, M.; Trejo-Valdivia, B.; Solano-Gonzalez, M.; MercadoGarcia, A.; Smith, D.; Hu, H. and Wright, R. (2007) : "Association between the plas$\mathrm{ma} /$ whole blood lead ratio and history of spontaneous abortion : a nested crosssectional study". BMC Pregnancy and Childbirth, 7:22-28.

Mannino, D.; Homa, D.; Matte, T. and Hemandez-Avila, M. (2005) : "Active and passive smoking and blood lead levels in U.S. adults :data from the third national health and nutrition examination survey". Nicotine Tab.Res.,7(4):557-564.

Masso, E.; Corredor, L. and Antonia, M. (2007) : "Oxidative damage in liver 
after prenatal intoxication with lead and/ or cadmium". J.Trace Elem. Med. Biol., 21:210-216.

Mckelvey, W.; Gwynn, R.; Jeffery, N.; Kass, D.; Thorpe, L.; Garg, R.; Palmer, C. and Parsons, P. (2007) : "A biomonitoring study of lead, cadmium and mercury in the blood of New York city adults". Environ. Health Perspect.,115:1435-1441.

Milnes, M.; Bermudez, T.; Bryan, T.; Edwards, M.; Gunderson, T.; Larkin, B.; Moore, B. and Guillette, L. (2006) : "Contaminant- induced feminization and demasculinization of non mammalian vertebrate males in aquatic environments". Environ. Res., 100:3-17.

Myatt, L. and Cui, X. (2004) : "Oxidative stress in the placente". Histochem. Cell. Biol., 122:369-382.

Nas, T.; Barun, S.; Oztruk, G.; Vural, J.; Ercan, Z. and Sarioglu, Y. (2007) : " Nicotine potentiates the electrical field stimulation-evoked contraction of non-pregnant rabbit myometrium". The Journal of Experimental Medicine, 211 (2): 187-193.

Osada, H.; Watanabe, Y.; Nishimura, Y.; Yukawa, M.; Seki, K. and Sekiya, S. (2002) : "Profile of trace element concentrations in the feto-placental unit in relation to fetal growth". Acta Obstet. Gynecol. Scand., 81:931-937.
Patrick, L. (2003) : "Lead toxicity, a review of the literature. Part I: exposure, evaluation, and treatment". Alternative Medicine Review, 11(1):2-22.

Ronco, A.; Arguello, G.; Munoz, L.; Gras, N. and Lianos, M. (2005 a) : "Metals content in placentas from moderate cigarette consumers. Correlation with newborn birth weight". Biometals, 18:233241.

Ronco, A.; Aguello, G.; Suozo, M. and Lianos, M. (2005 b) : "Increased levels of metallothionin in placenta of smokers ". Toxicology, 208: 133- 139.

Ronco, A. and Lianos, M. (2009) : "Fetal growth restriction is related to placental levels of cadmium, lead and arsenic but not with antioxidant activities". Reproductive Toxicology, 27: 88- 92.

Stockwell, P. and Corns, W. (1993) : "The role of Atomic Fluorescence Spectrometry in the automatic environmental monitoring of trace element analysis". J. Automatic Chem., 15: 79 - 84.

Synder, J.; Filipov, N.; Parsons, P. and Lawrence, D. (2000) : " The efficiency of maternal transfer of lead and its influence on plasma $\operatorname{IgE}$ and splenic cellularity of mice". Toxicol. Sci., 57:87-94.

Telisman, S. ; Cvitkovic, P.; Jurasovic, 
J.; Pizent, A.; Gavella, M. and Rocic, B. (2000) : "Semen quality and reproductive endocrine function in relation to biomarkers of lead, cadmium, zinc and copper in men". Environmental Health Perspectives, 108 (1): 45-53.

Telisman, S.; Colak, B.; Pizent, A.; Jurasovic, J. and Cvitkovic, P. (2007) : "Reproductive toxicity of low-level lead exposure in men". Environ. Res., 105: 256266.

Vanloon, J. (1985) : Selected Methods of Trace Metal Analysis: Biological and Environmental Samples. John Wiley \& Sons, New York, P.P. 211-221.
Wellinghausen, N. (2001) : "Immunobiology of gestational Zn deficiency". Br. J. Nutr., 85 (Suppl2): 581-586.

\section{World Health Organization (WHO)} (2000) : Safety evaluation of certain food additives and contaminants. WHO food additives series: 44, International Programme on Chemical Safety, Geneva.

Xu, D. X.; Shen, H. M.; Zhu, Q. X.; Chua, L.; Wang, Q. N.; Chia, S. E.; et al. (2003) : "The associations among semen quality, oxidative DNA damage in human spermatozoa and concentrations of cadmium, lead and selenium in seminal plasma". Mutat. Res., 534: 155-163. 


\title{
دراسة عقارنة لتركيز الرصاص، الكاد ميوم، الزنك والسلينيوم

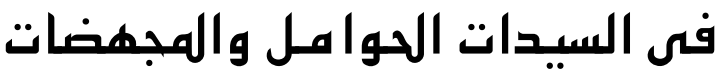

\author{
المشتركون فى البحث
}

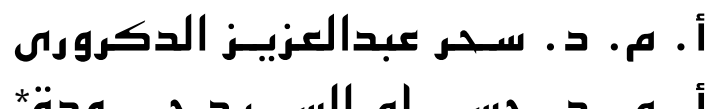

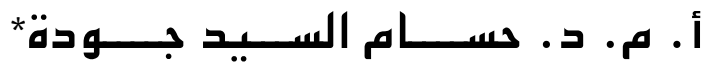

د. سهيله مـهمد الشربينى عطالله

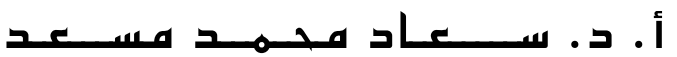

من أقسام الطب الشرعى والسموم الإكلينيكية والتوليد وأمراض النسا* - بكلية الطب - جامعة المنصسورة

الرصاص والكادميوم من المعادن التى لها تأثيرات حادة ومزمنة على الصحة بما فيها الصحة الإنجابية، ولأن السيدات الحوامل تعتبر أكثر

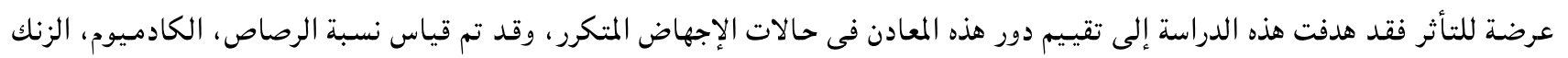

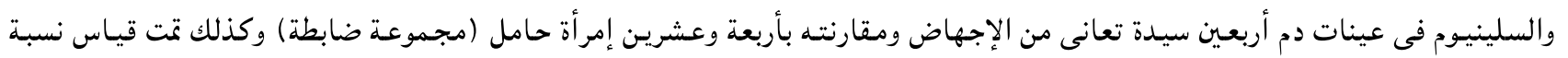
الرصاص والكادميوم فى ناتج الإجهاض ومقارنته بنسبته فى الدم.

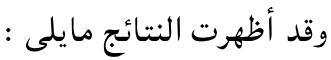

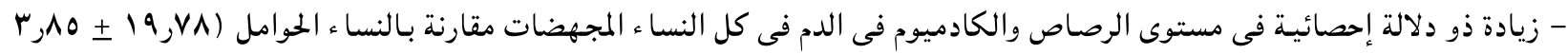

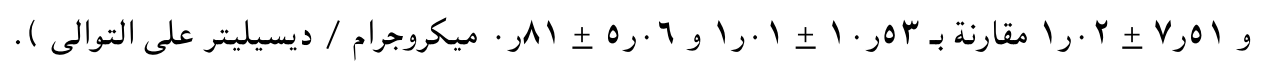

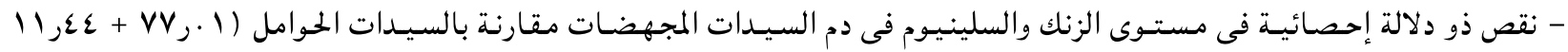

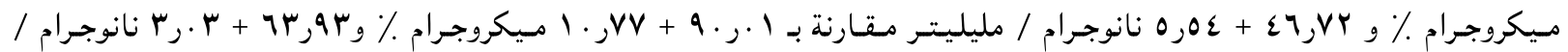
مليليتر على التوالى). - لوحظ إرتباط طردى بين مستوى الرصاص والكادميوم فى ناتج الإجهاض وفى دم السيدات المجهضات. - يتأثر مستوى الرصاص والكادميوم فى النساء باستعمال الكحل، الأوانى المطلية بالرصاص، الأغذية المحفوظة وكذلك التعرض للتدخين السلبى، كما يتأثر بوظيفة الزوج.

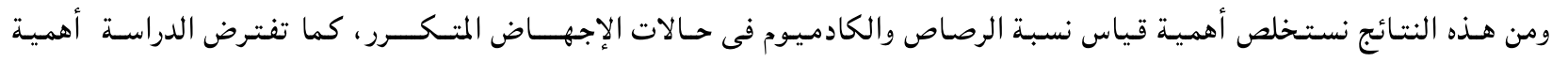

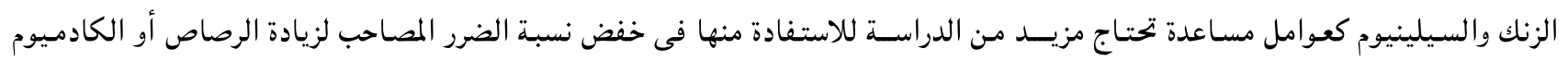

